\title{
Kompleks Anteusza. O starym i nowym regionalizmie
}

Kinga Siewior

TEKSTY DRUGIE 2019, NR 2, S. 117-131

DOI: $10.18318 /$ td.2019.2.10 | ORCID: 0000-0002-6858-233X

1.

Regionalizm na gruncie polskim wydaje się w pierwszej chwili pojęciem co najmniej ryzykownym. Na poziomie języka potocznego nasuwa skojarzenia z prowincjonalnością, zaściankowością lub folkloryzmem ewokowanym przez takie metafory jak skansen lub rezerwat. W ujęciu historycznym odsyła bądź do zjawisk formalnie i ideowo anachronicznych (jak poezja krajowego romantyzmu czy „antycywilizacyjna” twórczość grupy Czartak), bądź do nieraz emfatycznych stylizacji ludowych (vide młodopolska estetyzacja Podhala). Jako nazwa tendencji literackiej wyraża skrystalizowany w latach 20. program kulturalno-polityczny podporządkowany emancypacji obszarów zacofanych, która miała przebiegać przy jednoczesnym wytwarzaniu efektu integralności terytorium odrodzonego po zaborach II państwa polskiego. Ta, na pierwszy rzut oka pozostająca w sprzeczności z sensem literalnym pojęcia, unifikująca i w swych założeniach nacjonalistyczna

Kinga Siewior $-d r$, literaturoznawczyni, współpracowniczka Katedry Antropologii Literatury i Badań Kulturowych oraz członkini Ośrodka Badań nad Kulturami Pamięci na Wydziale Polonistyki UJ. Zajmuje się geopoetyką i kulturowymi studiami nad migracjami oraz środkowoeuropejskimi politykami i poetykami pamięci. Ostatnio opublikowała książkę Wielkie poruszenie. Pojałtańskie narracje migracyjne w kulturze polskiej (2018). 
funkcja regionalizmu utrzymuje się także po 1945 roku - po wojnie staje się narzędziem najczęściej agresywnej polityki miejsca prowadzonej przez władze peerelowskie na obszarach włączonych w granice państwa polskiego na mocy ustaleń konferencji w Jałcie. Idąc dalej: regionalizm zwykle konotuje słaby jakościowo weryzm; teksty klasyfikowane jako wtórne kopie modeli centralnych (kanonu narodowego) lub odwrotnie - literaturę wyabstrahowaną z szerszych kontekstów i tradycji, zorientowaną na konserwowanie raczej naiwnych wizji couleur locale. W sferze aksjologii przywodzi zaś na myśl koncepcje tożsamości esencjalistycznej lub „korzennej”, prymordializm i idee nieskażonej „rodzimości”, postawy kulturowego zamknięcia, niechęci wobec obcości i nowości.

Z wszystkich tych powodów kierunek ten nierzadko bywa rozpatrywany jako narzędzie ideologiczne: z jednej strony - etnicznych separatyzmów lokalnych; z drugiej - zazwyczaj agresywnej polityki narodowościowej skierowanej na niwelowanie kulturowych odrębności. Weryfikacji mariażu regionalizmu z politycznym instrumentalizmem z pewnością nie ułatwia również uwzględnienie kontekstów jego najbardziej rozpoznawalnych „światowych” realizacji - by wspomnieć rozwijającą się od XIX wieku w obszarze niemieckojęzycznym koncepcję Heimatliteratur lub też powojenne anglosaskie area studies. Pierwsza z nich, jak wiadomo, w międzywojniu wyewoluowała w kierunku nazistowskiej literatury krwi i ziemi (Blut-und-Boden-Literatur), druga - uznawana jest dziś za nieodrodne dziecko zimnowojennej goepolityki i geografii wiedzy.

Pisząc o ryzykowności posługiwania się terminem regionalizmu, myślę więc o grząskim gruncie skojarzeń i stereotypów, lecz również o umocowanych historycznie, geograficznie i ideologicznie zjawiskach kulturowych, które bynajmniej nie sprzyjają fundowaniu wokół niego nazwy nowej orientacji metodologicznej. A jednak, udało się: stwierdzić trzeba, że nowy regionalizm to fakt. Jako jeden z wyrazistszych nurtów w obrębie polskiego literaturoznawstwa po zwrocie topograficznym, stanowi skuteczną próbę przekierowania uwagi na fenomeny słabiej obecne w świadomości badawczej, gdyż umiejscowione, ujmując rzecz najoględniej, poza głównym nurtem literatury polskiej. I co nie mniej ważne, wskazując na rozmaite historyczne i aktualne warianty, uwarunkowania i konteksty tekstu regionalnego, nowy regionalizm zarazem podejmuje się istotnego przewartościowania samej procedury jego interpretacji. Czyni to w zgodzie z ogólniejszym kierunkiem wyłaniania się współczesnych cultural turns - respektując trzy, opisane przez Doris Bachmann-Medick warunki zwrotu jako takiego, a więc postulaty 
interdyscyplinarności, pluralizacji metod oraz przekształcania pojęć opisowych w pojęcia operacyjne'.

Wymierny efekt takich koncepcyjnych przesunięć stanowi seria Nowy regionalizm $w$ badaniach literackich, której kolejne tomy zostały poświęcone: (1) sondowaniu perspektyw regionalizmu jako metody badawczej w odnowionym obliczu (2012), (2) koncepcji regionalnych geografii wyobrażonych (2014), (3) relacji centralno-peryferyjnych w polskiej literaturze (2015), (4) kwestii tożsamości transgranicznych i translokacji (2016) oraz (5) pamięci i historii regionalnych $(2017)^{2}$. Tom otwierający serię wyznacza generalne zakresy nowatorstwa kierunku, pozostałe - uszczegółowiają słownik pojęć operacyjnych dla nowej orientacji kluczowych. Słownik ten nie wyczerpuje się jednak w parafrazowanych tutaj tytułach monografii, gdyż obejmuje jeszcze takie podstawowe geopoetologiczne kategorie jak miejsce, terytorium, lokalność, pogranicze, margines, krajobraz kulturowy, dyslokacja, przemieszczenie czy migracja. Ostatnie z nich wydają się szczególnie istotne, ponieważ odsyłają nie tylko do zjawisk historycznych decydujących o specyfice kulturowej znacznej części polskich regionów, lecz także do fluktuacyjnego charakteru nowego regionalizmu w ogólności. Wyróżnia go bowiem nieostrość i płynność granic: między tym, co miejscowe, partykularne, idiosynkratyczne, a tym, co światowe, uniwersalne, iteratywne; między ponowoczesnym kosmopolityzmem a będącą odpowiedzią na procesy globalizacyjne lokalnością; między tym, co prywatne, a tym, co publiczne; między tym, co formalne, a tym, co socjokulturowe; wreszcie - między tym, co określane jest mianem badawczego dystansu, a tym, co stanowi wyraz społecznikowskiego zaangażowania.

Naszkicowana w taki sposób, choć z konieczności w tym miejscu niedomknięta, siatka opozycji wyznacza meandryczne ścieżki działań noworegionalistycznych, które polegają na problematyzacji każdego z wyliczonych

1 D. Bachmann-Medick Cultural turns. Nowe kierunki w naukach o kulturze, przeł. K. Krzemieniowa, Oficyna Naukowa, Warszawa 2012, s. 17-32; Por. E. Rybicka Geopoetyka. Przestrzeń i miejsce we współczesnych teoriach i praktykach literackich, Universitas, Kraków 2014, S.15-20.

2 Nowy regionalizm w badaniach literackich. Badawczy rekonesans i zarys perspektyw, red. M. Mikołajczak, E. Rybicka, Universitas, Kraków 2012; Geografia wyobrażona regionu. Literackie figury przestrzeni, red. D. Kalinowski, A. Kuik-Kalinowska, M. Mikołajczak, Universitas, Kraków 2014; Centra-peryferie w literaturze polskiejXXiXXI wieku, red. W. Browarny, D. Lisak-Gębala, E. Rybicka, Universitas, Kraków 2015; Region a tożsamości transgraniczne. Literatura. Miejsca. Translokacje, red. D. Zawadzka, M. Mikołajczak, K. Sawicka-Mierzyńska, Universitas, Kraków 2016, Regionalizm literacki - historia i pamięć, red. Z. Chojnowski, E. Rybicka, Universitas, Kraków 2017. 
punktów odniesienia i badaniu zależności między nimi. Rozwinięcie tej nader ogólnikowej definicji można by natomiast osnuć wokół czterech, precyzowanych na różne sposoby w kolejnych noworegionalistycznych rozprawach, postulatów: decentryzacji, deterytorializacji, deesencjonalizacji i depolocentryzacji. Przy tym przedrostek „de" nie wskazywałby tu, rzecz jasna, na odrzucanie znaczeń związanych z procesami centryzacji, terytorializacji, esencjonalizacji i polocentryzacji, lecz na krytyczną z nimi dyskusję wynikającą ze świadomości tyleż ich opresyjności, co nieuchronności. W takim ujęciu decentryzacja odsyła więc do refleksji nad zależnościami i strukturami centralno-peryferyjnymi stanowiącymi dla literatury regionalnej, jak pisze Małgorzata Mikołajczak, „,prymarną matrycę, na której nadbudowane zostają inne kategoryzacje"3. Refleksja ta bierze pod lupę rozmaite geograficzne, polityczne, ekonomiczne i symboliczne konceptualizacje "centrum" i „peryferii”, kładąc szczególny nacisk na analizy modeli kształtowania ich wzajemnych relacji w skali rozciągającej się od postaw jawnie antycentralistycznych i konfrontacyjnych po postawy interakcjonistyczne, stawiające na demokratyczną i dialogiczną wizję wymiany kulturowej. Z kolei deterytorializacja - postulat w tym zestawie zapewne najbardziej frapujący ze względu na "terytorialny" charakter regionalizmu ex definitione - wiąże się, po pierwsze, nie tyle z negowaniem kategorii miejsca jako takiego, ile z uznaniem faktu, że nie jest ono konstruktem raz danym, lecz zmienną i czasową konfiguracją sensów geograficznych i społecznych. Po drugie, polega ona na konsekwentnym włączaniu w namysł nad regionem i twórczością regionalną historycznych doświadczeń dyslokacji: akcentowanie przechodniego i pogranicznego charakteru danych obszarów, uwzględnianie w ich opisie kwestii przemieszczeń między wsią i miastem, a przede wszystkim przyznanie powojennym przesiedleniom i migracjom wewnętrznym statusu podstawowej siły kulturotwórczej. Po trzecie, traktując przestrzeń jako dominantę tematyczną tekstu regionalnego, a zarazem akcentując w nim rozmaite aspekty powojennego wykorzenienia i współczesnego nomadyzmu, nowy regionalizm proponuje ruchome ramy jego interpretacji zgodne z ideą ponowoczesnej wędrówki pojęć. Z powyższym łączy się bezpośrednio postulat deesencjonalizacji, czyli odejście od myślenia wspólnoty i tożsamości lokalnej w kategoriach autentyczności, stałości czy przywołanej już "korzenności” w kierunku eksponowania ich konstruktywistycznej natury,

3 M. Mikołajczak Między mimikrą a rebeliq̨. Pejzaż (post)kolonialny regionalnej literatury, „Teksty Drugie" 2015 nr 5, s. 285. 
wyobrażeniowego charakteru, procesualności i hybrydyczności. Ostatnie z haseł, depolocentryzacja, oznacza natomiast rozluźnienie wiodących metanarracji narodowych na rzecz tropienia mikronarracji lokalnych uwzględniających punkty widzenia (doświadczenia, pamięć, historię) mniejszości, grup etnicznych deklarujących wobec polskości odrębność bądź też takich, które określać należałoby mianem skreolizowanych. W przesunięciu tym nie chodzi o prosty sprzeciw wobec Polski i polskości, ale o stereotypy, mity i fantazmaty, lub też, szerzej, o pewne „ograniczenia mentalne”, które, jak zauważa Zbigniew Chojnowski, wiążą się „z odnoszeniem nieomal wszystkiego do «sprawy polskiej»"4. Zamiast tego nowy regionalizm śledzi polifoniczny charakter kultur lokalnych, eksponuje nie podobieństwa, lecz różnice kulturowe, a owe polocentryczne „ograniczenia” poddaje krytyce jako jeden z elementów wspomnianych wyżej relacji centralno-peryferyjnych.

Tak projektowane kierunki lektury zyskują potwierdzenie w studiach przypadków, które wypełniają kolejne tomy wzmiankowanej serii. Z roku na rok coraz obszerniejsze, eksplorujące coraz rozleglejsze geografie wyobrażone i sondujące coraz głębiej przeszłość kultur lokalnych wydawnictwa te układają się w krytyczną historię porównawczą literatur regionalnych: śląskiej, kaszubskiej, podlaskiej, warmińskiej i lubuskiej (by wyliczyć kilka jaśniejszych „ognisk” owej refleksji). Nowy regionalizm jest jednak nie tylko strategią badawczą, której osią staje się opis historii i teraźniejszości odrębnych terytoriów w swej strukturze zazwyczaj pogranicznych, lecz także próbą metanarracji o świecie, którego owe terytoria stanowiły i stanowią część. A stąd przedstawia on ambicje donioślejsze niż deskrypcja określonych kultur lokalnych. Zdaje się bowiem wskazywać, jak w praktyce wygląda zaproponowana niegdyś przez Ryszarda Nycza alternatywna wobec przyjętej, możliwa historia literatury polskiej - historia oparta na matrycy pogranicza, konotująca „taką odmianę (i koncepcję) kultury, która nie ma swego centrum [...], w której centrum znajduje się granica, pojmowana jako próg kulturowych interakcji - kontaktów, konfrontacji, negocjacji, wymiany, hybrydyzacji"s. Ujmując rzecz krótko, nowy regionalizm realizowałby związany z ową matrycą postulat zmiany stereotypu Polski jako terytorium homogenicznego.

4 Z. Chojnowski Punkty wyjścia, punkty dojścia, w: Regionalizm literacki w Polsce. Zarys historyczny i wybór źródeł, red. Z. Chojnowski, M. Mikołajczak, Universitas, Kraków 2016, s. 452.

5 R. Nycz Możliwa historia literatury, "Teksty Drugie” 2010 nr 5, s. 178. 


\section{2.}

Wydany na przełomie roku 2016 i 2017, a pominięty we wcześniejszym wyliczeniu, zredagowany przez Małgorzatę Mikołajczak i Zbigniewa Chojnowskiego, czwarty tom serii, Regionalizm literacki w Polsce. Zarys historyczny i wybór źródet ${ }^{6}$ jest na tle pozostałych pozycją osobną, ale w zaproponowanym układzie nader pożyteczną. Gromadzi bowiem kilkadziesiąt powstałych na przestrzeni niemalże 120 lat wypowiedzi programowych, esejów, polemik, rozpraw teoretycznych i wyimków z obszerniejszych monografii tworzących zręby polskiego dyskursu regionalistycznego. Jego obraz dopełnia świetny szkic wprowadzający Mikołajczak, w którym - oprócz systematyzującego opisu kolejnych etapów rozwoju kierunku - pojawiają się także odniesienia do innych, licznych jego teoretyków i praktyków. Z jednej strony wszystkie te głosy pozwalają dociec okoliczności leżących u podstaw potocznej i niepozbawionej nuty pejoratywności charakterystyki nurtu, jaką pokrótce streściłam na samym wstępie niniejszego omówienia. Z drugiej trudno antologię rozpatrywać jedynie jako katalog zamierzchłych koncepcji, niefortunnych błędów i nierzadko paradoksalnych pomysłów na ich naprawę. Wręcz odwrotnie, zgromadzone w niej teksty można traktować jako rodzaj źródła, które nieprzerwanie zasila współczesną refleksję regionalistyczną. Korpus zagadnień poruszany w owej refleksji miałby zdaniem redaktorów tomu pozostawać stały.

I faktycznie, w zestawieniu wypowiedzi teoretyków i entuzjastów kierunku (m.in. A. Patkowski, S. Żeromski, E. Zegadłowicz, W. Orkan, S. Czernik, W. Arcimowicz, W. Gębik, Z. Hierowski), lecz także jego krytyków i denuncjatorów (m.in. Cz. Miłosz, K. Troczyński, I. Fik, E. Balcerzan, L. Bądkowski, J. Szczepański) oraz jego komentatorów i historyków (m.in. B. Chlebowski, S. Kolbuszewski, S. Skwarczyńska, E. Kuźma, R. Sulima, Z. Chojnowski) uwagę zwraca stały i zbieżny cel - wszyscy oni poszukują najbardziej adekwatnej względem swojego czasu i usytuowania definicji twórczości i działalności regionalistycznej. Od mniej więcej początku lat 30. XX wieku, a więc od momentu, gdy pojawiają się pierwsze mocniejsze głosy krytyczne wobec obowiązujących formuł regionalizmu, nieustannie powracającym motywem okazują się także rozmaite recepty na jego "uzdrowienie” i scenariusze jego "reinauguracji". Kolejną stałą, związaną bezpośrednio z żywiołem polemicznym, z jakim owa praca koncepcyjna ściśle się zespoliła, jest zaś nieskrywana ideologiczność nurtu. „I oto rzecz charakterystyczna: regionalizm skupia

6 Regionalizm literacki w Polsce... 
dokoła siebie pewną ideowość czy może raczej: regionalizm posiada wybitny dynamizm ideowy" - pisała Stefania Skwarczyńska w rozprawie Kierunek geograficzny z 1948 roku?. Jak w przypadku literatury regionalnej funkcje estetyczne i propagandowe odgrywają zazwyczaj równorzędne role, tak i w przypadku regionalistycznego literaturoznawstwa postawy badawcze i ideowe najczęściej bywają nierozdzielne. Przewrotnie rzecz ujmując, w tak określonym kontekście regionalizm należałoby więc rozumieć, za Mikołajczak, jako „zjawisko sui generis niegotowe, z założenia istniejące in statu nascendi" , którego główną dominantą okazuje się "permanentne różnicowanie" . Redaktorzy antologii konstruują ją jednak tak, aby z jej lektury można było wyłowić nieco konkretniejsze „parametry” owej zmienności, określające racje bytu kolejnych XX-wiecznych wcieleń nurtu. Pierwszy z nich łączyłby się ze wspomnianą wyżej postawą badawczą, wskazując zarazem na metodologiczną specyfikę kierunku; drugi - z postawą światopoglądową sygnalizującą z kolei jego oblicza ideologiczne.

Tak oto początki myśli regionalistycznej - reprezentowane w tomie przez Bronisława Chlebowskiego i jego rozprawę Znaczenie różnic terytorialnych, etnograficznych i związane z nimi odrębności ekonomiczno-społecznych, politycznych i umysłowych stosunków dla naukowego badania dziejów literatury polskiej (1884) - upływają pod znakiem genetyzmu i tainizmu, czyli orientacji, w których szczególny nacisk zostaje położony na tropienie powiązań twórcy i twórczości z jego miejscem urodzenia oraz ze środowiskiem, w jakim przychodzi mu żyć. Przyjęcie takiej perspektywy w przypadku Chlebowskiego owocuje koncepcją mapy-siatki - metody katalogowania zjawisk literackich w kluczu terytorialnym, w której idzie m.in. o „bliższe poznanie warunków, w jakich się wytwarzają pojęcia: Mazura, Litwina, Małopolanina"10. Model kartograficzny refleksji regionalistycznej rozwija się w międzywojniu, kiedy to w jej centrum znajdują się, jak byśmy dziś powiedzieli, analizy miejsc autobiograficznych i socjologia lokalnych środowisk twórczych. W każdym z tych przypadków

7 S. Skwarczyńska Kierunek geograficzny, w: Regionalizm literacki w Polsce..., s. 288.

8 M. Mikołajczak Wstęp: Regionalizm w polskiej refleksji o literaturze, w: Regionalizm literacki wPolsce..., s. 10.

Por. E. Rybicka Geopoetyka..., s. 346.

B. Chlebowski Znaczenie różnic terytorialnych, etnograficznych i zwiq̨zane z nimi odrębności ekonomiczno-społecznych, politycznych i umysłowych stosunków dla naukowego badania dziejów literatury polskiej, w: Regionalizm literacki w Polsce..., s. 93. 
wskazywanie kulturowych, geograficznych, ale i osobniczych różnic jest traktowane jako mapowanie dziedzictwa narodowego.

Na czas intensywnej realizacji tej formuły regionalizmu przypada już jednak krystalizowanie się innej jego definicji - kreślonej z pozycji strukturalistycznych. Jeden z pierwszych jej propagatorów, Konstanty Troczyński, pisał w roku 1933 o regionalizmie jako o nurcie „obniżającym kulturę środków pisarskich, wymagając techniki prostackiej i przezwyciężonych i skompromitowanych metod sugestii artystycznej"11. Wątek deprecjacji regionalizmu jako nurtu pozbawionego „samoistnej nadbudowy” ergo reprezentującego nikłe wartości estetyczne rozwija się oczywiście najmocniej w okresie powojennym, gdy - jak przewidywała Skwarczyńska - „zwrócą się i przeciw temu kierunkowi wszystkie zarzuty skierowane przeciw kierunkom skrajnie pozaergocentrycznym i poietocentrycznym"12. Dominacja strukturalizmu, a więc modelu właśnie ergocentrycznego, w pewnej mierze przyczynia się do marginalizacji badań regionalistycznych oraz utożsamiania literatury regionalnej z literaturą ludową bądź też literaturą popularną, czyli z niskim obiegiem artystycznym. Ukoronowaniem tych tendencji staje się teoria Erazma Kuźmy (1987), który przedstawia definicje kierunku na podstawie komunikacyjnego modelu „input-output” - twierdzi on mianowicie, że o regionalności tekstu, poza zazwyczaj słabą jakością estetyczną, decyduje wąski zakres jego społecznego oddziaływania (obieg regionalny) oraz fakt, że każdorazowo przyjmuje on więcej treści z zewnątrz (z obiegów centralnych) niż produkuje własnych ${ }^{13}$. Warto dodać, że takowa ocena nurtu utrzymuje się nie tylko w gronie zdeklarowanych strukturalistów, lecz także wśród przedstawicieli peerelowskiej krytyki regionalistycznej konsekwentnie apelujących o literaturę regionalną, która przekroczyłaby próg prostej formalnie „ludowości” i „popularności”14.

W okresie dominacji nastawienia strukturalistycznego ponownie jednak pojawiają się już antycypacje innej, konkurencyjnej wobec obowiązującej definicji regionalizmu: na powrót egzocentrycznej lub też, by ująć rzecz językiem dziś nam bliższym, kulturowej. Tak więc Lech Bądkowski w artykule Nie chodzi o rezerwat - ale o konstruktywna sitę (1961) podejmując się dyskusji

11 K. Troczyński Regionalizm w literaturze, w: Regionalizm literacki w Polsce..., s. 171

12 S. Skwarczyńska Kierunek geograficzny (kierunek naukowy i regionalistyczny), w: Regionalizm literacki w Polsce..., s. 295.

13 E. Kuźma Współczesny regionalizm jako rodzaj komunikacji literackiej, w: Regionalizm literacki w Polsce..., s. 379-384.

14 Zob. Z. Kubikowski W raju fałszywych ambicji, s. 329-340. 
z propagowaną przez władze peerelowskie wizją „cepelianej” literatury ludowej, postuluje zastąpienie zdefraudowanej estetycznie i znacjonalizowanej idei regionalnej pojęciem małej ojczyzny („mnie natomiast chodzi o społeczny, wychowawczy, konstruktywny sens umiłowania małej ojczyzny, wewnątrz jej małej społeczności"15). Stanisław Pietraszko, uwzględniając przemiany modernizacyjne i kwestie powojennych migracji, w roku 1970 proponuje definicję regionu jako „nowej formuły odrębności i tożsamości kulturowej”"16. "Nową regionalizację" widział natomiast jako zjawisko wynikające ze świadomych działań ludzkich w środowisku naturalnym, którego przekształcanie „będzie środkiem samoidentyfikacji, będzie też swoistym znakiem własnej, «tutejszej» tradycji, a ta jest niezbędna w kształtowaniu lokalnej mitologii, w której to społeczność ludzka odnajduje i utrwala swoją zbiorową tożsamość"17. Z kolei Roch Sulima w szkicu W stronę literatur regionalnych (1982) upomina się, aby w namyśle nad nimi uwzględniać perspektywę antropologiczną: „zagadnienie relacji między kulturami regionalnymi a kulturą ogólnonarodową stawiane było najczęściej w sposób formalistyczny jako relacja pomiędzy «niższym» i «fragmentarycznym» a «wyższym» i «całościowym», z pominięciem problematyki antropologicznej, jaka rysuje się w centrum tej problematyki"18. Etnolog apeluje również o przejście z substancjalnego do relacyjnego modelu postrzegania kultur regionu, przez który rozumie „intelektualny kontakt z tradycją regionalną [realizowaną - przyp. K.S.] jako różnicowanie lub integralne postrzeganie istniejących w literaturze formuł ludzkiego losu"19.

Wszystkie te głosy, które traktować trzeba jako wołanie o bardziej konstruktywną i sprawczą, pluralistyczną i demokratyczną, humanistyczną i antropologiczną refleksję regionalistyczną, znajdują swoje dopełnienie w ostatnim z tekstów antologii - we fragmencie rozdziału Punkty wyjścia, punkty dojścia z książki Zbigniewa Chojnowskiego „Zmartwychwstały kraj mowy”. Literatura Warmii i Mazur lat dziewięćdziesiątych (2002). Wyimek ten, będący po części rekonstrukcją dyskursu literatury małych ojczyzn oraz projektu regionalizmu

\footnotetext{
15 L. Bądkowski Nie chodzi o rezerwat-ale o konstruktywnq̨ siłę, w: Regionalizm literacki w Polsce..., S. 321-322. 
ponowoczesnego Kazimierza Brakonieckiego i olsztyńskiej Borussii, stanowi - w zgodzie ze swoim tytułem - nie tyle tylko domknięcie opowiadanej na łamach antologii historii polskiego regionalizmu, lecz także rodzaj tematycznej i personalnej klamry, która łączy wydawnictwo z pozostałymi tomami serii.

Druga, ideologiczna, ścieżka definiowania regionalizmu zyskuje swój wyraźny kontur w pierwszej dekadzie międzywojnia. Jak wspominałam, początki zorganizowanego ruchu regionalistycznego przypadają na okres tuż po odzyskaniu niepodległości. Aleksander Patkowski, widząc w kierunku instrument, który pozwoli zniwelować nader żywotne po 1918 roku podziały rozbiorowe, w Ideach przewodnich regionalizmu (1924) jego funkcje określał następująco:

Regionalizm wysuwa hasło odrodzenia wartości rasowych polskich, wzmożenia poczucia przynależności terytorialnych [...] Przez wszechstronne poznanie ziemi i człowieka regionalizm budzić ma zmysł organizacyjny, dar inicjatywy, umacniać dyscyplinę egzekutywy, szerzyć zamiłowanie do konstrukcji i konkretności, wykrzesać, słowem, energię narodową. ${ }^{20}$

Regionalizm w ujęciu jego międzywojennych ideologów jest ruchem ogólnonarodowym, zakłada systemowy rozwój lokalnych instytucji naukowych i kulturalnych oraz wsparcie dla rozmaitych regionalnych inicjatyw społecznych, traktując literaturę jako jeden z ważniejszych kanałów przepływu owej „energii narodowej”. W praktyce szczególnie żywotny okazuje się jednak na obszarach buforowych II Rzeczypospolitej (Wileńszczyzna, Kaszuby, Śląsk czy też szeroko rozumiana Polska Zachodnia), gdzie stanowi, ujmując rzecz najoględniej, narzędzie animacji polskiej tożsamości w warunkach pogranicznych. Antologia przybliża zaś przede wszystkim działania literackie w tym celu podejmowane. Przykładowo, Gustaw Morcinek, pisząc w afirmatywnym tonie o tradycji śląskiego regionalizmu, główną jego rolę widzi w sprzeciwie wobec „zachłanności czeskiej i niemieckiej”, literaturę śląską postrzega zaś głównie jako medium konserwujące „to, co się jeszcze dało uratować przed Czechami i Niemcami”, które dopiero w sytuacji niepodległości „stara się na podłożu swojszczyzny śląskiej tworzyć nowe wartości kulturalne, mające wzbogacić kulturę ogólnopolską"21. Z kolei Czesław Miłosz, próbując z pozycji krytycznych uchwycić tytułowy Sens regionalizmu (1932), twierdzi wprost, że

20 A. Patkowski Idee przewodnie regionalizmu, w: Regionalizm literacki w Polsce..., s. 121.

21 G. Morcinek Regionalizm ślq̨ski, w: Regionalizm literacki w Polsce..., s. 166. 
choć w pierwszych latach II Rzeczypospolitej nurt ten był na Wileńszczyźnie uzasadniony, to w ciagu dekady wyewoluował w kierunku ,zasady bezwzględnego asymilowania Białorusinów, Litwinów, zasady pięści w stosunku do mniejszości”22; stał się „środkiem wprowadzającym do ziem wschodnich kulturę polską w dawkach mniej jaskrawych, w pigułkach sprzedawanych pod nazwami «tutejszości»"23, a przy okazji wykreował obraz Wilna i Wileńszczyzny jako „partykularza, zupełnej prowincji”"24. Mechanizm owej prowincjonalizacji wedle Miłosza wyglądałby natomiast tak:

tam, gdzie wynędzniały chłop, stojąc przed chatą, mruczy wściekłe przekleństwa na przejeżdżających autami burżujów, ci burżuje widzą tylko rozczulającą scenę rodzajową [...] jak wzruszająco głupi jest ten „dziaduk",jak umysłowość jego przypomina umysłowość dziecka. Ale za to jaki nasz, jaki „tutejszy”. 25

O regionalizmie jako szczególnego rodzaju kolonizacji wsi wypowiada się w podobnym tonie także Ignacy Fik (1935), który za jego podstawową „zasadzkę" uznaje fakt, że właściwie od samych swych początków był to program zorientowany na „ratowanie kultury narodowej tj. szlachecko-ziemiańskiej przed «niszczącym wpływem cywilizacji»”26. W latach międzywojennych ów trend antycywilizacyjny, rozwijany m.in. przez grupę Czartak i Stanisława $\mathrm{Czernika}^{27}$, doprowadza zdaniem Fika do zakrycia realnych problemów wsi związanych z jej modernizacją oraz z emancypacją polityczną klasy chłopskiej: „kokardy, piosenki i parzenice splotły się w tęczową firankę, w której fałdach ukrywano skrzętnie najważniejsze sprawy społeczne i polityczne"28. Krytyk upomina się zaś o regionalizm zaangażowany, zaktualizowany o świadomość zachodzących przemian politycznych i obyczajowych oraz uwrażliwiony na

24 Tamże, s. 159.

25 Tamże.

26 I. Fik Zasadzki regionalizmu, w: Regionalizm literacki w Polsce..., s. 198.

27 E. Zegadłowicz Wywodzimy się z ziemi (1928), J. Birkenmajer O regionalizmie „Czartaka” (1933),

S. Czernik Regionalizm w poezji współczesnej (1934).

28 I. Fik Zasadzki regionalizmu, w: Regionalizm literacki w Polsce..., s. 198. 
kwestie społeczne, a więc o regionalizm, który „jest usprawiedliwiony o tyle, o ile przestaje być regionalizmem burżuazyjnym"29 .

Przytaczam wszystkie te barwne cytaty, gdyż celnie wskazują na główne kierunki ewolucji nurtu w międzywojniu oraz sygnalizują obszary napięć, które określały wówczas dyskusję regionalistyczną. Odzwierciedlają one drogę od postrzegania regionalizmu jako ruchu patriotycznego opartego na wciąż jeszcze żywych imperatywach romantycznego „umiłowania ojczyzny” oraz pozytywistycznej „ochrony” jej kulturowego dziedzictwa w początkowej fazie niepodległości w stronę wykorzystywania go jako narzędzia polityki narodowościowej w okresie rządów sanacyjnych, kiedy to zaczyna przybierać niekiedy kształty ruchu o cechach jawnie nacjonalistycznych. Ponadto, pokazują one jak inicjatywa, która początkowo działać miała na rzecz młodej i nowoczesnej państwowości, w rzeczywistości upowszechniała sensy antymodernizacyjne i umacniała regresywne oblicze owej państwowości.

Wspominam te wypowiedzi jednak również dlatego, że po II wojnie światowej, czyli w momencie, gdy sytuacja polityczna i ideologiczna w kraju uległa całkowitemu odwróceniu, dyskusja regionalistyczna wciąż toczy się w podobnych ramach. Chociaż więc regionalizm traci swój „burżuazyjny” rys, a jednym z jego ważniejszych patronów staje się właśnie Fik, to ponownie do rangi jego głównej funkcji urasta konsolidowanie terytoriów włączonych w granice państwa po jałtańskiej korekcie mapy ${ }^{30}$. I dalej: chociaż „sprawa chłopska” i modernizacja z oczywistych przyczyn są wtedy tematem pierwszoplanowym, a na czołową tradycję regionalistyczną wybijają się górnośląskie dzieje kierunku³1, to ponownie w mocy pozostaje problem folkloryzacji kultury wiejskiej traktowanej przede wszystkim jako ostoja „rdzennie” polskich tradycji.

Można by więc zaryzykować uogólnienie, że XX-wieczny regionalizm polski realizował model kultury, który wspomniany był wcześniej, Nycz nazywa właśnie rdzenną: „ekskludującą poza swe granice to wszystko, co inne bądź hybrydyczne; [...] odwróconą od swych ściśle wyznaczonych granic, w pobliżu których rośnie niebezpieczeństwo, że do głosu i istnienia dojść może to wszystko, co skażone, gorsze i nieczyste"32. Jednocześnie owej monocentrycznej tendencji, jak pokazuje antologia, niezmiennie towarzyszyły

Tamże, s. 202.

Zob. W. Gębik Regionalizm jako czynnik wspólnoty narodowej, 1961.

Zob. Z. Hierowski W służbie regionalizmu i przeciw regionalizmowi. Teoria i praktyka, 1969.

R. Nycz Możliwa historia literatury, s. 178. 
alternatywne wizje regionalizmu - otwartego, wielokulturowego i progresywnego społecznie. Owo drugie stanowisko, co być może paradoksalne, reprezentuje większość przywoływanych przeze mnie autorów, dyskutujących wszak prawie zawsze z (niekorzystną) sytuacją zastaną.

3.

Na zakończenie chciałabym wspomnieć o jeszcze jednym paradoksie wyłaniającym się z lektury Regionalizmu literackiego w Polsce, który wynika z kodyfikacyjnego charakteru zgromadzonych w tomie tekstów. Mianowicie: przez sporą ich część przewija się myśl o tym, że najlepsze przykłady twórczości i działalności regionalnej powstają spontanicznie, bez regionalistycznych etykiet i deklaracji - gdy pisanie staje się wyrazem doświadczenia najbliższej przestrzeni. Jest to podstawowy wyznacznik regionalizmu, który jednak właśnie ze względu na swoją niewątpliwość gubi się czasami w gąszczu teoretycznych ustaleń i ideologicznych polemik. Podkreślmy więc, że utwór regionalny jest próbą oddania specyfiki miejsca, z którego spogląda się na świat, tekstualnym zagospodarowywaniem przestrzeni na podstawie konkretu geograficznego i przyrodniczego, jak i doświadczeń duchowych i historycznych rodzinnych stron. Z tych też względów za patrona nurtu uznaje się mitycznego Anteusza, syna Gai i Posejdona, którego moc odradzała się za sprawą dotyku Matki-Ziemi.

Dominujące w dyskursie regionalistycznym afirmatywne odczytania tej opowieści akcentują wątek cudownej siły czerpanej z najbliższego otoczenia, która staje się symbolem (i motorem) twórczości regionalnej. Mit ten ma jednak również swoją mroczną stronę - Anteusz telluryczne moce wykorzystywał do zabijania przechodzących przez jego krainę wędrowców, których czaszkami zdobił następnie świątynię ojca. Został pokonany dopiero przez Herkulesa, który udusił giganta w powietrzu. Opowieść o Anteuszu wyraża więc także obsesyjne pragnienie zachowania stałego punktu oparcia, lęk przed obcością oraz sytuację zamknięcia, w której twórcza energia służy podtrzymywaniu kultu ojców. W jeszcze szerszym ujęciu bywa zaś rozpatrywana jako metafora procesów globalizacji, w której to, co stare, przegrywa z nowym - uosobionym w postaci Herkulesa, herosa związanego z żywiołem powietrza, swobodnie wędrującego po świecie po to, aby w kolejnych swych pracach obalać zastane porządki33.

33 Zob. P. O'Connor Home: The Foundations of Belonging, Routledge, New York 2018, s. 8-23 (rozdz. Antaeus and Hercules). 
Owa wieloznaczność mitu, którą proponuję tu nazywać kompleksem Anteusza, wyznacza ramy refleksji regionalistycznej prezentowanej w antologii. Określa granice (i ograniczenia) nurtu, lecz także zarysowuje postulowany horyzont jego (auto)transgresji, która - krótko rzecz ujmując - zasadzałaby się na pragnieniu zachowania szczególnych więzi z przestrzenią przy jednoczesnym przechwytywaniu heraklejskiej postawy swobody i otwartości. W takim ujęciu, by przywołać myśl cytowanego już Sulimy, „nie idzie o to, jak pisarzy wiąże miejsce urodzenia, ale o to, na jaki rodowód świadomie się skazują, w jakim miejscu na ziemi chcą zobaczyć świat cały, jak uczynił to choćby Bruno Schulz, William Faulkner, Erskine Caldwell, Carlos Fuentes, Gabriel Garcia Márquez, Miodrag Bulatović, Czingiz Ajtmatow, Julian Stryjkowski, Tadeusz Nowak, Edward Redliński i Wiesław Myśliwski"34. Chciałoby się dodać: i jak uczynił to Czesław Miłosz, a później Kazimierz Brakoniecki.

Oprócz zbieżnej perspektywy oglądu rzeczywistości i wierności lokalnym mikrokosmosom, owo zacne grono twórców łączy również biograficzne doświadczenie dyslokacji, wędrówki z geograficznych peryferii do symbolicznych centrów (kanonów) oraz skłonność do prowadzenia zagorzałych dyskusji z przyjętymi definicjami narodu i nieodmienne opowiadanie się po stronie heterogenicznych wzorców tożsamości. Z tych też względów niewątpliwie bliżej byłoby im do tego, co dziś definiuje się jako nowy regionalizm. Obecność w antologii owych nazwisk (i postaw za nimi się kryjących) wskazuje zatem nie tylko na to, że (auto)transgresja regionalizmu jest możliwa, lecz także na to, że nowy regionalizm w gruncie rzeczy nie tyle zrywa z tradycyjnym regionalizmem, ile realizuje od dawna pokładane w tym kierunku nadzieje. Regionalizm literacki w Polsce pozwala ową ciągłość dostrzec. 


\section{Abstract}

\section{Kinga Siewior}

JAGIELLONIAN UNIVERSITY (CRACOW)

The Antaeus Complex: Old and New Regionalism

Review: Regionalizm literacki w Polsce:Zarys historyczny i wybór źródeł [Literary Regionalism in Poland: Historical Outline and Selected Sources], ed. by Z. Chojnowski, M. Mikołajczak, Universitas, Cracow 2016, 452 pp.

\section{Keywords}

new regionalism, space, locality, centres, peripheries, Polish literature 